Elżbieta Zawadzka-Bartnik

Uniwersytet Warszawski

\title{
REFLEKSJA W ZAWODZIE NAUCZYCIELA - ZAŁOŻENIA A REALNE MOŻLIWOŚCI REALIZACJI
}

\author{
Reflection in the teaching profession - foundations \\ and real possibilities for implementation
}

\begin{abstract}
The category of reflection has a long tradition in education. The aim of this article is to focus on the reasons for the difficulties of putting this construct into practice and on educational consequences of this, as well on some paradoxes in education today. Among the main reasons for the difficulties are discussed: the interpretation of reflection, the disregard for the specifics of the profession of the FL teacher in curriculum standards and administrative regulations and the negative influence of market-oriented ideology on education and teacher training. The lack of comprehension of, and/or the misinterpretation of the idea of reflection have negative consequences for education and teacher training. The article concludes with some suggestions for the teacher and pupil education, including a broadly understood idea of reflection.
\end{abstract}

Keywords: category of reflection in education, paradoxes, idea of reflection, implementation, teacher training

Słowa kluczowe: kategoria refleksji w edukacji, paradoksy idea refleksyjności, realizacja, kształcenie nauczycieli

\section{Wprowadzenie}

Wprowadzenie kategorii refleksji do nauczania ma już kilkudziesięcioletnią tradycję. Zwłaszcza od lat 80. kategoria ta stanowiła przedmiot analiz, dyskusji, konferencji i ma już bardzo bogatą literaturę. $W$ moim artykule przypomnę zatem tylko główne zagadnienia związane z koncepcją refleksji. Celem 
moim będzie natomiast skupienie się na przyczynach trudności w jej realizacji i edukacyjnych skutkach, a także na towarzyszących im w odniesieniu do kategorii refleksji paradoksach w obecnej rzeczywistości edukacyjnej.

\section{Kategoria refleksji - jej przypomnienie}

Choć rozważania o refleksji w dydaktyce można znaleźć w literaturze fachowej już od lat 60. XX w., to kategoria ta rozwinęła się szczególnie w latach osiemdziesiątych i najbardziej jest związana z koncepcją refleksyjnej praktyki Schöna (1983). Schön czerpał inspiracje z prac Deweya z lat 30. XX wieku, który wywarł znaczny wpływ na współczesne sposoby określania znaczeń edukacyjnych refleksji wyróżniając działanie rutynowe (wyznaczone tradycją) i refleksyjne (powiązane z namysłem i analizą). Refleksja to wg Schöna swoisty rodzaj myślenia towarzyszący działaniu, rodzaj reakcji nauczyciela na sytuacje, które trudno rozwiązać odwołując się jedynie do posiadanej już wiedzy i umiejętności. Źródłem refleksyjnego działania jest pewien typ umysłowości związany z myśleniem refleksyjnym, które implikuje stadium wątpienia, niepewności, odczuwania trudności, a także aktywnego poszukiwania właściwego rozwiązania. Refleksja to pewien proces intelektualny, polegający na strukturyzacji, bądź restrukturyzacji doświadczenia i posiadanej wiedzy, narzędzie pozwalające odkryć złożoność zjawisk, przeciwdziałać rutynie, stereotypowemu postępowaniu, a także tendencji do polegania na intuicji (Kwiatkowska, 1997: 142 i in.).

W literaturze znajdziemy opisy różnych rodzajów refleksji. Przyjmując, że refleksja zawodowa/pedagogiczna nauczyciela to jego namysł, analizowanie oraz wyprowadzanie rozważnych i uprawomocnionych wniosków ważących na zawodowych decyzjach, rozpatruje się ją za Schönem głównie $w$ aspekcie refleksji w działaniu i refleksji nad działaniem. Refleksja w działaniu przebiega z nim równocześnie, jest krytycznym zakwestionowaniem założeń własnej wiedzy, umożliwia dostosowanie działania do konkretnej sytuacji i prowadzi do jego modyfikacji. Refleksja nad działaniem dokonywana jest natomiast z pewnego dystansu czasowego, dzięki czemu może być bardziej wszechstronna i pogłębiona. Stanowi inny jakościowo aspekt namysłu. Jej przedmiotem jest rozważanie alternatyw, uwzględnianie różnych punktów widzenia, przy czym oba typy refleksji rzadko występują w formie izolowanej (Mizerek, 1999: 77).

Zbliżonym do pojęcia refleksji w działaniu jest refleksyjna praktyka, której ważną cechą jest zdolność do tworzenia nowych wartości poznawczych w sytuacjach pedagogicznego działania. Warunkiem jej funkcjonowania jest wysoki poziom kompetencji profesjonalnej, rozumianej jednak nie jako biegłość wykonywania powtarzalnych zachowań, ale jako umiejętność radzenia 
sobie z nowymi, unikatowymi sytuacjami. Z koncepcją refleksji wiążą się także tzw. badania w działaniu (Elliott, 1991) - podejście badawcze, w którym badacz jest aktywnym uczestnikiem i łączy działanie z refleksją, praktyką i teorią, w celu rozwiązania zaistniałych problemów dydaktycznych. Przyjmuje się, że najbardziej wartościową i charakteryzującą refleksyjnego nauczyciela, jest jego samorefleksja (Kotusiewicz, 2008: 23) polegająca na połączonych z krytycznym myśleniem i samooceną świadomych i przemyślanych wysiłkach pozwalających poprzez samoregulację i samoocenę na doskonalenie się w zawodzie.

\section{Znaczenie i zalety refleksji}

Krytycznymi atrybutami czy właściwościami refleksji (obejmującej refleksję w działaniu i nad działaniem, refleksyjną praktykę, badania w działaniu, refleksję profesjonalną itp.) jest identyfikacja problemu uznanego za istotny, tworzenie wielu możliwych jego rozwiązań, weryfikacja oraz wdrożenie nowego rozwiązania. Takie działania pozwalają nauczycielowi na lepsze zrozumienie uwarunkowań determinujących działania dydaktyczne, umożliwiają krytyczną i twórczą zmianę z wykonawcy cudzych pomysłów w nauczyciela kreatywnego i innowacyjnego, świadomego i odpowiedzialnego za wyniki własnej pracy. Refleksja pozwala nauczycielowi uwolnić się od stereotypów i dogmatów, a także doprowadzić do zmiany leżących u ich podstaw teorii osobistych, tj. nieuświadomionych subiektywnych przekonań składających się z własnych doświadczeń, zreinterpretowanych treści naukowych lub doświadczeń innych osób, schematów lekcji, wyobrażeń. Jest podstawą do krytycyzmu wobec własnych działań i wpływa także na wzrost refleksyjności uczniów (Czerepaniak-Walczak, 1997:19, 25 i in.). Badania dotyczące zalet refleksyjnego kształcenia nauczycieli wykazały większą zdolność nauczycieli do strukturyzacji sytuacji i problemów, łatwość definiowania celów ucznia i uznanie ich samodzielności, zdolność do analizy własnego funkcjonowania w relacjach interpersonalnych i łatwość nawiązywania kontaktów z uczniami, większe poczucie bezpieczeństwa, pewności siebie, osiąganie wyższego stopnia satysfakcji z pracy (Dylak, 1996: 55). Uczenie się bycia refleksyjnym nauczycielem, to uczenie się refleksji w stosunku do własnych doświadczeń dydaktycznych, przyjęcie zasady systematycznego kwestionowania własnej praktyki. Refleksyjne myślenie wraz z autorefleksją i samokontrolą pozwala na wyłanianie problemów i podejmowanie prób ich rozwiązania, sprawdzanie trafności, uruchamianie twórczego myślenia.

To wszystko o refleksji w zawodzie nauczyciela, jej zaletach dla efektywnego procesu nauczania i uczenia się już przecież wiemy - dlaczego za- 
tem znowu, mimo bogatej literatury na ten temat, mimo przekonania wielu nauczycieli co do roli tej kategorii w edukacji wracamy do tego problemu? Jakie są przyczyny obserwowanego zaniechania bądź nie podjęcia działań zmierzających do wdrożenia idei refleksyjności (obejmującej w moim rozumieniu wszelkie formy refleksji - refleksję w działaniu i nad działaniem, autorefleksję, refleksyjną praktykę, refleksję zawodową, refleksję nad zawodem itp.) przez samych nauczycieli i przez decydentów edukacyjnych? Dlaczego, od co najmniej kilkunastu lat, coraz częściej jesteśmy konfrontowani z administracyjnymi paradoksami, rozporządzeniami ograniczającymi refleksję, a nawet zmierzającymi wręcz do działań przeciwstawnych tej idei?

\section{Próba wyjaśnienia sytuacji}

Realizacja idei refleksyjności w zawodzie nauczyciela nie jest (z bardzo wielu powodów) łatwa, do tego zależna od wielu czynników, z których najistotniejsze (w moim odczuciu) chciałabym przeanalizować. Przytoczę główne przyczyny trudności i zaniedbań w realizacji zamierzeń z lat 90. dotyczących kategorii refleksji związane z nadmiernym uproszczeniem samego pojęcia refleksji i jej przedmiotu, z trudnymi warunkami realizacji. Omówię skutki nieznajomości i/lub braku uznania specyfiki zawodu nauczyciela, zwłaszcza nauczyciela języków obcych (JO) i warunków jego pracy, a także niekorzystny w kontekście kategorii refleksji wpływ ideologii rynkowej na edukację i kształcenie nauczycieli.

\subsection{Trudności $w$ rozumieniu/interpretacji i realizacji kategorii refleksji oraz wynikające $z$ nich zaniedbania}

Choć pojęcie refleksji i koncepcja refleksyjnego nauczania są traktowane jako jedne z centralnych kategorii współczesnej edukacji nauczycielskiej i stanowią od lat 80. przedmiot wielu badań, brak jest do tej pory jednolitego rozumienia refleksji, co powoduje liczne kontrowersje. Pojęcia refleksji zawodowej nauczyciela nie znajdziemy ani w Słowniku Psychologicznym Szewczuka (1985) ani w Słowniku Pedagogicznym Okonia (1987), czy w Encyklopedii Pedagogicznej (1993). Niedookreśloność pojęć wchodzących w zakres refleksji zawodowej prowadzi do swoistej dowolności interpretacji samej kategorii refleksji, często do nadużywania tego pojęcia bez uwzględnienia jego głębokiego sensu (Czerepaniak-Walczak, 1997: 10). Mylące dla nauczyciela i nie zawsze jednoznacznie rozumiane mogą być też pojęcia zbliżone, choć nie tożsame, jak wymieniane już refleksyjne czy krytyczne myślenie, refleksyjna praktyka, refleksja zawodowa/pedagogiczna, autorefleksja, które (nie wnika- 
jąc jednak w rozróżnienia) w dalszej części referatu będę rozumiała łącznie jako kategorię, ideę refleksji czy refleksyjności.

Główne trudności i zaniedbania w realizacji idei refleksji wynikają z uwarunkowań psychologicznych, nadmiernego uproszczenia pojęcia refleksji i jej przedmiotu, z silnego oddziaływania teorii osobistych, z niedoskonałości kształcenia prowadzącej do niedostatecznej wiedzy profesjonalnej nauczyciela, a także z braku zapewnienia odpowiednich warunków organizacyjnych. Bezrefleksyjne działanie jest wygodniejsze i łatwiejsze - refleksja wymaga bowiem poważnego wysiłku poznawczego i zależy od pewnego typu umysłowości oraz zasobów intelektualnych nauczyciela. Refleksja narusza z natury rzeczy pewność, stabilność i rutynowość działań nauczyciela, powodując pewien dyskomfort psychiczny. Jej tworzywem są sprzeczności poznawcze, co oznacza konieczność posiadania przez nauczyciela wiedzy o różnej proweniencji metodologicznej (por. Kwiatkowska, 1997: 155).

Podstawą potocznego usprawiedliwienia dla niechętnie realizowanej idei refleksji jest zawężenie pojęcia refleksji głównie do obszarów instrumentalnych i łączenie przez nauczyciela zazwyczaj z koniecznością równoczesnej z podejmowanymi działaniami obserwacji i analizy oraz szybkim podejmowaniem adekwatnych decyzji (por. Czerepaniak-Walczak, 1997: 16-17). Pominięte zostają inne obszary refleksji, jak refleksja nad sobą w zawodzie i życiu osobistym, nad tym czego uczymy, a co powinno być głównym celem nauczania, nad ukrytym programem, tj. mimowolnym, nieświadomym nauczaniem czegoś, co nie jest oficjalnie ujęte w programie, a nawet może być z nim sprzeczne itp.

Pewną blokadę w uruchomieniu refleksji stanowią tzw. teorie osobiste, tworzące pewność prowadzącą do rutyny, która jest przeciwieństwem refleksji. Teorie osobiste stanowią rodzaj sita poznawczego powodującego, że akceptowane są informacje potwierdzające nasze wyobrażenia i odrzucane te, które podważają słuszność naszych przekonań (Zawadzka, 2001).

Źródło trudności w realizacji idei refleksji stanowi także niedostatek wiedzy profesjonalnej, rozumianej jako rzetelna, holistyczna oraz systematycznie aktualizowana wiedza, która może być źródłem zawodowych inspiracji, stanowić podstawę głębokiego namysłu i autonomicznych decyzji nauczyciela. Rozproszona podczas kształcenia wiedza teoretyczna, nieuwzględniająca często specyfiki nauczania i uczenia się języków obcych, nieprzystawalność teorii w zazwyczaj rozumianym znaczeniu do praktyki edukacyjnej, wynikająca ze skomplikowanych między nimi związków, nie ułatwia refleksji i daje poczucie „zadomowienia” prowadzącego do pewników i rutyny, uniemożliwiając jednocześnie dystans do zaistniałych problemów dydaktyczno-wychowawczych. 


\subsection{Nieuwzględnienie specyfiki zawodu nauczyciela języków obcych w programach kształcenia nauczycieli i w rozporządzeniach administracyjnych}

Innym ważnym źródłem trudności w realizacji idei refleksji w edukacji jest (moim zdaniem) niezrozumienie i nieuznanie specyfiki zawodu nauczyciela, zwłaszcza nauczyciela JO. Zawód nauczyciela jest zawodem szczególnym z wielu powodów. W tym zawodzie nie chodzi głównie o przekaz wiedzy, ale o uczenie samodzielności poznawczej i egzystencjalnej, wyjaśnianie i interpretowanie, animację aktywności samokształceniowej, stymulację twórczego myślenia itp. Nauczyciel to człowiek wielowymiarowy, a bycie nauczycielem to znacznie więcej niż wykonywanie zawodu. Jest to profesja trudna, o wysokim stopniu złożoności i odpowiedzialności społecznej.

Zawód nauczyciela należy do grupy tzw. zawodów społecznych, w których praca wymaga konieczności stałej bliskiej styczności psychicznoemocjonalnej z innymi, angażując całą osobowość. Podmiotem pracy nauczyciela jest człowiek, ale $\mathrm{w}$ odróżnieniu od $\mathrm{np}$. zawodu lekarza nie pojedyncza osoba, lecz grupa/klasa, co stanowi jednocześnie o komunikacyjnym charakterze pracy nauczyciela i wynikających z tego konsekwencjach. Kompetencje komunikacyjne nauczyciela to jednak nie tylko dająca się technicznie opanować umiejętność przekazywania informacji, to umiejętność precyzyjnego, poprawnego i skutecznego jej formułowania z uwzględnieniem wieku, poziomu intelektualnego i możliwości poznawczych uczniów, umiejętność aktywnego słuchania i empatycznego rozumienia treści i intencji wypowiedzi ucznia, wykorzystywania języka werbalnego i niewerbalnego w edukacyjnym porozumieniu, zdolność do bycia w dialogu z innymi i rozwiązywania konfliktów z wykorzystaniem wiedzy o komunikacji interkulturowej (por. Kwaśnica 2004: 300). Kompetencje komunikacyjne zawierają zatem w pewnych zakresach kompetencje społeczne, rozumiane jako skuteczne, akceptowane społecznie funkcjonowanie w kontaktach z innymi, obejmujące poprawną komunikację, empatię, asertywność, udzielanie wzmocnień społecznych itp.

Zawód nauczyciela to zawód niestandardowy, twórczy i innowacyjny. Sytuacje pedagogiczne są bowiem (mimo - za Kwiatkowską, 1997: 56 błędnej opinii na ten temat prawie $25 \%$ nauczycieli) nieprzewidywalne i niepowtarzalne. $\mathrm{O}$ ile $\mathrm{w}$ innych zawodach rutyna świadczy o wysokim poziomie rozwoju zawodowego, to w zawodzie nauczyciela nie jest ona pożądana, daje bowiem pewność, która kryje w sobie przewidywalność i przyczynowość zdarzeń, a tego w zawodzie nauczyciela brak. Sytuacje pedagogiczne zależą od wielu czynników i to właśnie właściwa ich interpretacja będąca rezultatem odpowiednio przetworzonej wiedzy teoretycznej i głębokiej refleksji wyznacza kierunek i sposoby podejmowania działań edukacyjnych. 
Stała zmienność sytuacji pedagogicznych, konieczność natychmiastowej reakcji i niemożność bezpośredniego przełożenia świadczonego wysiłku na efekty, stanowią dla nauczyciela źródło wielu trudności i obciążeń, których rezultatem jest wzrost napięcia emocjonalnego, znużenie psychiczne, towarzysząca mu atmosfera niepokoju i obaw. Nadmiar zadań i brak warunków ich rzetelnego wykonania przy coraz wyższych wymaganiach stawianych przez rozwój nauki i postęp techniczny, poczucie osamotnienia, wywołuje, przy specyficznym rodzaju odpowiedzialności nauczyciela wynikającym z powierzonych obowiązków i wysokich oczekiwań społecznych, długotrwały stres powodujący znacznie częściej występujące niż w innych zawodach tzw. wypalenie zawodowe.

Zawód nauczyciela wymaga stałego doskonalenia, ponieważ nie jest produktem finalnym akademickiego kształcenia. Kwalifikacje nauczycielskie nie mogą mieć formy skończonej, gdyż nauczycielem się staje w wyniku rozwoju. Założenie o pełnym przygotowaniu zawodowym nauczyciela jako efekcie studiów pozostaje $w$ sprzeczności $z$ istotą jego pracy, a wymagane kompetencje są ze swej natury zawsze niegotowe i wciąż niewystarczające (por. Kwaśnica, 1994: 10). Profesjonalność nauczyciela to nie tylko fachowość, ale jednocześnie spełnienie wymagań najwyższych standardów poznawczych, działaniowych, etycznych.

Do wymienionych trudności w realizacji idei refleksji wynikających ze specyfiki zawodu należy dodać problemy nauczyciela JO, dla którego język ten jest jednocześnie przedmiotem nauczania i środkiem komunikacji. Nauczanie języka nie polega - jak wiadomo - na przekazywaniu gotowego materiału, ale na kształtowaniu odpowiednich umiejętności, co wymaga dużej kognitywnej aktywności uczących się, zaangażowania i czasu, a także tworzenia przez nauczyciela odpowiednich warunków. Rzutuje to na konieczność posiadania przez nauczyciela języków obcych specyficznego rodzaju wiedzy profesjonalnej (obejmującej także umiejętności i postawy), wiedzy będącej wynikiem badań glottodydaktyki i stwarzającej nauczycielowi szansę wieloaspektowości poznania, analizy, weryfikacji i dostosowywania działań dydaktycznych do stale zmieniających się sytuacji.

Nieuwzględnienie specyfiki językowej, choćby w formie aneksu do standardów kształcenia nauczycieli JO, mimo zgłaszanych Ministerstwu przez PTN postulatów, doprowadziło do dominacji zajęć ściśle psychologicznopedagogicznych nad glottodydaktycznymi bez oczekiwanej aplikacji teorii komunikacyjnych, psychologicznych i pedagogicznych do nauczania języków obcych, w wyniku czego (przy ograniczonym czasie zajęć i liczebnych grupach) tak ważna w tym zawodzie idea refleksyjności (w różnych jej odmianach) nie jest realizowana, powodując utrwalanie nie zawsze słusznych teorii osobistych i powielanie nie zawsze efektywnych działań. 


\subsection{Wpływ ideologii rynkowej na edukację i kształcenie nauczycieli}

Perspektywa rynkowa sprowadziła problemy edukacji do kwestii rachunku ekonomicznego, do myślenia w kategoriach opłacalności, bilansu zysku i strat. Dla zwiększenia wydajności następuje ograniczanie edukacji do niezbędnego minimum, bezkrytyczne i bezrefleksyjne podporządkowywanie treści i metod kształcenia założeniom standardowym, "testomania” obejmuje wszystkie poziomy kształcenia. Uczniowie traktują uczenie się zazwyczaj instrumentalnie jako narzędzie budowania kariery, przez co jest ono uproszczone, odtwórcze, ograniczone do minimum wysiłku (por. Cylkowska-Nowak, 2013: 302-6). Dla nauczycieli najważniejsza staje się realizacja rozporządzeń służących głównie statystykom, nie mają oni czasu na refleksję ani nie widzą jej celowości. Tak zalecane nauczycielom w latach 90. kształtowanie autonomii ucznia, jego samokontroli i refleksji nad własną nauką staje się zwyczajną fikcją.

Masowość studiów, powszechna dostępność i komercjalizacja uczelni powodują, że nierzadko głównym motywem podejmowania studiów wyższych (także obejmujących kształcenie nauczycieli) jest uzyskanie dyplomu jako drogi do wymiernej finansowo kariery. U znacznej grupy studentów (podobnie jak i uczniów), trud studiowania/uczenia się zamieniony został w trud kombinowania dla ukrycia braku wiedzy. Nastąpił znaczny wzrost różnego typu zjawisk patologicznych - ściąganie, plagiaty, czy fałszywe dyplomy. Zanika coraz bardziej potrzeba wiedzy ogólnej, kreatywności, autonomii (por. Potulicka, 2010: $317 \mathrm{i}$ in.). Wiedza nie służy też pogłębieniu prawdy o życiu, do własnego rozwoju, ale ma być pragmatyczna, do zastosowania. Podporządkowanie szkół wyższych dyktatowi praw rynkowych, tego co słuszne i wartościowe skutecznemu i opłacalnemu, prowadzi niestety do utraty autonomii i zaniechania ściśle z nią związanej refleksji. Refleksyjność z punktu widzenia ekonomii jest przecież nieefektywna. Nie wytwarza wiedzy do natychmiastowego zastosowania, ani nie jest produktem rynkowym, pozwala jedynie dostrzec skomplikowaną sytuację wielowymiarowej rzeczywistości (Bauman, 2003: 54).

Nauczyciel akademicki kształcący nauczycieli staje przed dylematem między własnym systemem wartości i rozumieniem roli kształcenia a oczekiwaniami studenta, tworzenie zwodniczych statystyk i działania pozorne wypierają rzeczywiste dokonania (Potulicka, 2011: 89). Na jakąkolwiek refleksję brak czasu i chęci. Pozorne zwiększanie efektywności uczelni jest osiągane przez redukcję kosztów. W programach kształcenia nauczycieli następuje coraz większe ograniczanie wiedzy humanistycznej na rzecz wąskiego profesjonalizmu, a właściwie technik nauczania wg zewnętrznych standardów czy Krajowych Ram Kwalifikacyjnych ukierunkowanych na poszczególne umiejęt- 
ności i sprawności. Na problematykę etyczną zawodu, problemy wychowawcze, społeczne itd., nie ma już czasu.

W kształceniu nauczycieli coraz bardziej rezygnuje się ze wszystkiego, co nie ma wartości pieniężnej, bezpośrednio praktycznej i utylitarnej dla uczelni, instytutu, a więc także z rozwijania specyficznych i niezwykle istotnych umiejętności nauczycieli JO, o których wspominałam. Edukacja nauczycieli jest traktowana głównie jako zło konieczne. Dominuje model szybkiego uzyskiwania kwalifikacji nauczycielskich. Przeznaczenie jedynie 150 godz. na metodykę nauczania (także języków obcych) uniemożliwia realne przygotowanie do zróżnicowanych zakresów zawodowych. Znaczne powiększenie (ze względów oszczędnościowych) ilości studentów w grupach utrudnia efektywne odbywanie praktyk, a także realizację idei refleksji w jakiejkolwiek postaci.

\section{Skutki niezrozumienia i/bądź zaniechania realizacji idei refleksji - stan edukacji, kształcenia nauczycieli i doskonalenia}

Podczas konferencji „Edukacja w Polsce” w styczniu 2013 r. (Śliwerski, 2013) wybitni pedagodzy twierdzili, że politykę oświatową cechuje chaos, upartyjnienie, krótkofalowość oraz brak spójności, a poszczególne podsystemy są dysfunkcyjne, co jest sprzeczne z konstytucyjną zasadą demokracji oraz równości szans i wzywali do przemyślenia całościowej polityki edukacyjnej państwa. Mówiono o umasowieniu fikcyjnego wykształcenia wyższego, w którym dyplomy nie mają pokrycia w kompetencjach absolwentów. Krytycznie stanowisko zajęto wobec kolejnych „reform urzędniczych” - także tych związanych z wdrażaniem w szkołach wyższych systemu bolońskiego. Wg ekspertyzy Komitetu Nauk Pedagogicznych PAN szkoła okazuje się skansenem kulturowym, nie tylko nie zapewniającym kompetencji do radzenia sobie we współczesności, ale wręcz pielęgnującym kompetencje bezużyteczne. Nigdzie nie jest tak wysoko oceniana odtwórczość, schematyczność, brak oddolnej inicjatywy i koncepcyjności, jak w szkolnej klasie (Klus-Stańska, 2008: 26). Wg Raportu IBE (2011) polscy uczniowie mają znaczne trudności w zadaniach wymagających samodzielnego wnioskowania i stawiania hipotez czy argumentowania. Lawinowo narasta strefa korepetycji, co pogłębia nierówności kulturowe i zagraża marginalizacją. Pewna poprawa wyników w badaniach PISA nie jest skutkiem radykalnej zmiany formuły edukacji szkolnej, lecz czarno- i wolnorynkowych usług edukacyjnych. Tegorocznej matury nie zdało 19\% 60 tys. uczniów (19 tys. z 2 przedmiotów).

Wizerunek nauczycieli w badaniach ponad 1100 studentów oceniających swoje doświadczenia szkolne (Knasiecka-Falbierska, 2010: 178) nie jest 
optymistyczny. Nauczyciele rzadko stwarzają uczniom warunki do podmiotowego funkcjonowania, rzadko podejmują w relacjach z uczniami działania zachęcające ich do samodzielności, w niewielkim stopniu stwarzają możliwości rozwoju umiejętności poznawczych i wrażliwości na rzeczywistość. Tworzy się różnego typu fikcje, bagatelizuje różne formy nieuczciwości ucznia.

Wg badań Helsińskiej Fundacji Praw Człowieka (2010: 25 i in.) wynika, że polskie szkoły ogólnodostępne nie są przygotowane do nauczania włączającego, przy ca $15 \%$ uczniów z orzeczeniem poradni psychologiczno-pedagogicznych. Wielu nauczycieli nie wie, czym są indywidualne programy nauczania, nie potrafi sprostać problemom wychowawczym, nie zna podstaw programowych itd.

Oficjalnie głosi się podmiotowość, autonomię, kreatywność i twórczość jako istotne zasady nowoczesnej edukacji, a wprowadza standardy i kontrolę realizacji podstaw programowych. Podkreślana jest rola samodzielności, samooceny (por. Portfolio językowe), a decydująca jest standaryzowana kontrola, często w postaci zero-jedynkowych testów i rozbudowane procedury biurokratyczne. Akcentuje się rolę indywidualizacji, a dominuje rywalizacja i konkurencja. Ponieważ reforma edukacji przynosi konsekwencje przeciwstawne pierwotnym założeniom i podlega zawłaszczaniu przez doraźne interesy polityczne i ekonomiczne, w dokumentach VI Kongresu Obywatelskiego z 2011 r. zaleca się wręcz „odejście od tępej standaryzacji w szkole i pracy nad kompetencjami w kierunku podmiotowości uczniów i nauczycieli”.

O poziomie kształcenia nauczycieli brak jest systematycznej wiedzy. Przerzucanie się odpowiedzialnością za kształcenie nauczycieli między Ministerstwem Edukacji Narodowej i Ministerstwem Szkolnictwa Wyższego i Nauki nie służy sprawie. Kształcenie nauczycieli w Polsce odznacza się pełnym bałaganem, sprzecznościami, skrajną różnorodnością i woluntaryzmem, a na wyższych uczelniach traktowane jest po macoszemu. Minimalne wymagania programowe, zwane od 2001 r. standardami kształcenia, odnoszą się głównie do przedmiotów, liczby godzin, a ostatnio efektów i narzucają konieczność realizacji wielu cząstkowych przedmiotów w niewielkim wymiarze godzin. Wielość ścieżek uzyskiwania kwalifikacji nauczycielskich (też studia podyplomowe lub kursy kwalifikacyjne) utrudnia zapewnienie i kontrolę jakości (por. np. Półturzycki, 2008).

Trudno oprzeć się wrażeniu, że w kształceniu, szczególnie zaś nauczycieli, mamy do czynienia z wyraźnym regresem. Podejście kompetencyjne w takim ujęciu jak to jest obecnie propagowane stoi w sprzeczności ze specyfiką zawodu nauczyciela i podstawowymi zasadami pedagogiki humanistycznej. W kształceniu nauczycieli wracamy do modelu technicznego (wg typologii Kwiatkowskiej), tj. zdominowanego przez behawiorystyczne podejście polegające na wydzielaniu poszczególnych elementów, ich ćwiczeniu i sprawdzaniu. Odrzuca się lub bagatelizuje problematykę aksjologiczną, a normy moralne, etyczne, społeczne tracą na 
znaczeniu. Zapomina się o wieloaspektowości, niepowtarzalności i indywidualizacji procesu nauczania i wychowania. Obniżenie we wprowadzanej reformie kształcenia wyższego ze względów finansowych wymagań i poziomu nauczania (dwu magistrów zamiast doktora, dwu doktorów zamiast profesora itd.), świadczy wyraźnie o tym, że decydentom zabrakło wiedzy i refleksji odnośnie do wagi kształcenia nauczycieli dla całości rozwoju kraju.

Wśród czynnych zawodowo nauczycieli znacznie wprawdzie wzrósł procent nauczycieli z wyższym wykształceniem, ale kształcenie i doskonalenie nauczycieli jest - jak pisze Denek (2008: 46) piętą achillesową reformy systemu edukacji. Mamy także niestety do czynienia z odwróconą piramidą awansu (IBE, 2011) - ponad połowa nauczycieli ma najwyższy stopień zawodowy, a wysokie wymagania i zbyt małe korzyści finansowe nie motywują nauczycieli do rzeczywistego podnoszenia kwalifikacji (nie zawsze także mają oni na to czas czy fundusze). Wg raportu NIK (za: PaP 30.10.2012) 1/3 nauczycieli nie podnosi swoich kompetencji 1/5 nauczycieli, którzy podnieśli swoje kwalifikacje, nie otrzymała przydziału zajęć odpowiadających ich przygotowaniu. Niewystarczająca liczba publicznych placówek doskonalenia nauczycieli powoduje, że nie realizują one znacznej części obowiązujących zadań (na 1 doradcę metodycznego przypada ca 600 nauczycieli).

Jeśli chodzi o studia doktoranckie na uczelni, to nie bardzo wiadomo, czemu mają służyć, czy jest to miejsce przygotowania do pracy naukowej, czy forma przedłużenia studiów. Na ile jest to fałszywa obietnica pozostania na uczelni, na ile jedynie czas odroczenia spotkania z rynkiem pracy i odpowiedzialnością (por. Czerepaniak-Walczak, 2011). Na studiach tych, które cieszą się dużą popularnością, gdyż idą za nimi pieniądze z resortu, jest dziś w Polsce wg danych MNiSW ponad 40 tys. słuchaczy, 1/3 z nich otrzymuje stypendia, ale dyplom doktora otrzymuje jedynie co 8 z nich (za: Raszkowska, Rzeczpospolita 11.05.2013), czym uczelnie się już specjalnie nie interesują.

Przedstawiony stan to m.in. wynik niezrozumienia bądź zaniechania realizacji idei refleksji w edukacji, a przede wszystkim błędnych, silnie zdominowanych przez ideologię rynkową rozporządzeń będących próbą pogodzenia w pracy nauczyciela i w jego kształceniu czegoś, co nie da się pogodzić, jak np. coraz silniejszej technologizacji, standaryzacji i utowarowienia kształcenia z podmiotowością, autonomią, krytycyzmem, kreatywnością, refleksją nauczyciela i ucznia itp. Na potwierdzenie kilka przykładów z życia:

- $\quad 87 \%$ dyrektorów szkół publicznych przyznaje się (wg komitetu PAN) do zawyżania ocen i „przepychania” ostatnich klas dla uzyskania wyższej jakości pracy szkoły.

- Studenci kierowani bywają na praktykę pedagogiczną do szkół, które często (z powodów organizacyjnych, finansowych, kadrowych) stają 
się szkołą przetrwania, a nie miejscem zdobywania zakładanych doświadczeń dydaktycznych.

- Wdrażanie opracowanego przed kilkunastoma laty do wszystkich etapów kształcenia Portfolio zostało z powodu niedostatecznego przygotowania nauczycieli i braku czasu bezmyślnie zaniechane, czego skutkiem jest zaprzepaszczenie szansy przygotowania do autonomii i refleksji. Wg badań Marciniak (cyt. w ORE) 3/4 badanych nauczycieli znało Portfolio, 1/4 była przekonana o korzyściach, ale tylko 4 nauczycieli systematycznie zachęcało uczniów do pracy z nim, a 14 jedynie o nim opowiadało.

- W ORE, gdzie jest Wydział Rozwój kompetencji społecznych i obywatelskich organizuje się szkolenie nauczycieli dotyczące Miejsca edukacji ekonomicznej na różnych etapach kształcenia (ekonomia w praktyce w gimnazjum).

- Profesor przyjmuje na seminarium 30 magistrantów a nawet doktorantów (chyba dla zaspokojenia swoich ambicji czy potrzeb finansowych, bo efektywna zindywidualizowana praca z nimi nie jest przecież możliwa).

- W publikacji z 2012 r. opracowanej w ramach programu Kapitał ludzki współfinansowanego przez UE dotyczącej modyfikacji programu kształtowania kompetencji kluczowych w zakresie języków obcych, przeznaczonej chyba do doskonalenia nauczycieli, jako jedną z nowocześniejszych metod nauczania JO wymienia się sugestopedię (dla przypomnienia: Losanow lata 60.), utożsamia „proces uczenia się języka”, z „procesem zapamiętywania", do nauczania gramatyki proponuje się dryle językowe, zalecana jest ",metoda oparta na nauce poprzez testowanie" a opracowanie wzbogacone jest fragmentami strony internetowej $z$ radami: Jeśli nie znasz odpowiedzi, zawsze strzelaj, pamiętaj, że B lub C stanowią najczęściej poprawną odpowiedź itd. Jest to brak refleksji nie tylko autorek, ale też osób, które publikację dopuściły do druku.

I jeszcze przykład doskonalenia doktorantów i kadry dydaktycznej także w ramach Programu Kapitał ludzki UE. Szkolenia z Dydaktyki Szkoły Wyższej mają zachęcić kadrę naukowo-dydaktyczną do ... , pokazać jak ... i udowodnić, że można znaczq̨co podnieść efektywność prowadzenia zajęć. Tzw. Zajęcia wizytowane mają na celu podanie informacji zwrotnej dotyczącej umiejętności dydaktycznych pracowników. Formularz wizytacyjny zajęć wypełnia szkoleniowiec wraz z osobą prowadzącą zajęcia. Rezultat: to wzrost wiedzy i umiejętności pracowników, otrzymanie szczegółowej informacji zwrotnej i sprawienie, że uczelnia stanie się uczelniq kształcqca w nowoczesny sposób. Wykładowca nie jest oceniany pod względem merytorycznym (czemu trudno się dziwić), gdyż na 15 ekspertów/szkoleniowców tylko 4 osoby mają wykształcenie pedago- 
giczne, reszta to trenerzy z zakresu przedsiębiorczości, właściciele firm, trenerzy firm doradczych dotyczących marketingu, firm szkoleniowych dla kadry menedżerskiej, grup terapeutycznych, zarządzania w gospodarce, czy prezes agencji reklamowej - ale ocenia się: Czy nauczyciel akademicki jest przygotowany do zajęć, tj. - czy dba o wywietrzenie sali, wytarcie tablicy, przedstawia cel zajęć i podsumowuje je, czy aktywizuje studentów oraz w jaki sposób mówi (?), a na podstawie raportów ma powstać poradnik dobrych praktyk (por. Majewska, 2013). Szkolenie jest dla doktorantów obowiązkowe. Inni co kilka lat mogą "Odświeżyć metodykę nauczania" - No comment! - To tylko wybrane dowody braku refleksji i odpowiedzialności decydentów w wielu dziedzinach naszej edukacyjnej rzeczywistości.

\section{Propozycje - co warto zrobić, jak kształcić (nauczycieli i uczniów)}

Kategorię refleksji w zawodzie nauczyciela, też nauczyciela szkoły wyższej, jako kategorię psychologiczną i filozoficzną warto - moim zdaniem - rozumieć szerzej, raczej jako namysł wynikający z odpowiedzialności zawodowej i etycznej, jako refleksję nad zawodem i jego specyfiką, refleksję nad sobą w zawodzie, jako osobą i profesjonalistą (autorefleksja), refleksję nad uczniem/studentem, co jest dla niego ważne i potrzebne nie tylko dziś, ale na przyszłość, refleksję nad wartościami i światem, nad paradoksami programów kształcenia i rozporządzeń administracyjnych.

Dla bardziej efektywnej realizacji idei refleksji niezbędne wydają się zmiany sposobu kształcenia nauczycieli. Truizmem jest stwierdzenie, że tylko odpowiednio kształcony nauczyciel będzie umiał przygotować innych do refleksyjnego funkcjonowania w coraz bardziej złożonej rzeczywistości, będzie uczył rozumienia i właściwego hierarchizowania wartości, przygotowywał do życia społecznego i samorealizacji. Podstawę kształcenia powinna stanowić zintegrowana w czasie studiów z praktyką wiedza teoretyczna, w której dominuje układ problemowy nad przedmiotowym a efektem kształcenia akademickiego powinna być nie tyle wiedza zewnętrznie „dana” (poprzez studia), co wiedza samodzielnie odkrywana $\mathrm{w}$ indywidualnym procesie poznania (Kwiatkowska, 2011: 89). We współczesnym świecie tracą na znaczeniu kwalifikacje w postaci gotowej wiedzy i wyspecjalizowanych umiejętności, a zyskują te, które są podstawą zachowań innowacyjnych, twórczych. Im bowiem bardziej złożony, różnorodny, zmienny jest świat, w którym człowiek żyje i działa, tym, bardziej złożona, różnorodna i elastyczna musi być jego wiedza i jego poznawczo-regulacyjne umiejętności (Kwiatkowska, 2008: 140). 
Do realizacji zadań dydaktyczno-wychowawczych nauczycielowi nie wystarcza zatem tzw. wiedza praktyczna „jak sobie poradzić w danej sytuacji”, dlatego głoszony przez studentów jak i niekiedy nauczycieli JO a ostatnio silnie eksponowany przez zarządzenia obu Pań Minister pogląd, jakoby nauczyciel potrzebował w pracy głównie praktycznych rozwiązań, nie zaś wiedzy teoretycznej, a zatem studia i dokształcanie nauczycieli powinno mieć charakter praktyczny, należy - moim zdaniem - traktować jako bezzasadny, gdyż krytyczny stosunek do wiedzy teoretycznej wynika głównie z niewłaściwego rozumienia jej roli. Wiedza taka nie służy bowiem do bezpośredniego zastosowania w praktyce, ale stanowi niezbędną podstawę refleksji, analizy i interpretacji sytuacji dydaktyczno-wychowawczych.

Zdominowana przez ideologię rynkową rzeczywistość edukacyjna wymaga powrotu do propagowanej w latach 90. zeszłego wieku filozofii kształcenia, odwołującej się do wartości uniwersalnych, sprzyjających samorealizacji, wielostronnemu rozwojowi człowieka i pomagających w rozwiązywaniu jego problemów, a nie realizacji zalecanego przez Panie Minister upraktycznienia i urynkowienia. Bez zrozumienia idei humanistycznej (też idei refleksji) nauczyciel JO nie będzie mógł skutecznie realizować ani swych zadań dydaktycznych ani wychowawczych. Pogłębiający się kult profesjonalizacji i specjalizacji spowodował postępujące pojmowanie roli szkoły jako terenu nabywania wyłącznie określonej wiedzy instrumentalnej. Zagubiona została - jak się wydaje refleksja nad podstawowym sensem edukacji tj. w jaki sposób i w jakim zakresie może ona pomóc młodemu człowiekowi w rozwiązywaniu problemów egzystencjalnych, doskonaleniu osobowym, w wyjaśnianiu i rozumieniu coraz bardziej skomplikowanej rzeczywistości, przygotowaniu do życia w świecie pluralizmu moralnych wartości i konieczności wyborów.

Do realizacji idei refleksji trzeba jednak nauczycieli przygotować, zapewnić obok wiedzy profesjonalnej kształtowanie odpowiednich cech (np. wysoka refleksyjność, skłonność do podejmowania ryzyka poznawczego), umiejętności (podejmowania eksperymentów myślowych i krytycznego sprawdzania wywodów) i właściwych postaw dotyczących samokształcenia, innowacyjności, kreatywności, a zwłaszcza postawy refleksyjnej i gotowości stosowania refleksji do rozwiązywania problemów dydaktycznych i wychowawczych (por. CzerepaniakWalczak, 1997: 91 i in.). Pomocne mogą być w tym względzie np. kwestionariusze samooceny nauczyciela proponowane przez Wysocką (1998: 96 i in.), znane nam Portfolio nauczyciela, a także elementy treningu interpersonalnego, warsztaty czy badania w działaniu.

Refleksji w nauczaniu i uczeniu się nie da się zadekretować poprzez standardy, opis kompetencji czy efektów. Od wyszczególniania co nauczyciel „powinien”, formułowania efektów „uczeń/student rozumie, pozna, nauczy 
się, będzie wiedział" skoro on (z bardzo różnych powodów) nie potrafi zrozumieć, nie chce poznać i się nauczyć, nie podniesie się ani jakość edukacji szkolnej, ani nauczycielskiej. Trudno zatem zrozumieć, dlaczego oba Ministerstwa tak bezkrytycznie starają się znormalizować edukację na wzór dziedzin ekonomicznych, skoro zarówno w Polsce, jak i innych krajach realizujących model rynkowy edukacji tzw. podejście oparte na efektach kształcenia podlega ze względu na bardzo słabe wyniki ostrej krytyce (Thieme, 2009). Zamiast mnożenia opisów kompetencji, umiejętności, kwalifikacji bardziej potrzebna jest nauczycielowi i uczniowi umiejętność całościowej interpretacji problemów współczesnego świata, postawa gotowości do podejmowania wyzwań, otwartości na zmianę, także chęci ciągłego uczenia się i reagowania na zmieniającą się rzeczywistość. Tego ani szkoła, ani uczelnia dziś nie uczy.

Państwo nie może się zrzekać odpowiedzialności za politykę edukacyjną, zwłaszcza w stosunku do nauczycieli. Powinna ona być pod kontrolą państwa i stanowić spójną koncepcję, określać cele, wyznaczać warunki funkcjonowania, definiować prawa i obowiązki (por. Szempruch, 2000: 108-110). Większy nacisk w kształceniu nauczycieli warto położyć na założeniach aksjologicznych i kompetencjach komunikacyjnych oraz społecznych. Zajęcia z psychologii i pedagogiki należałoby powierzać osobom posiadającym także wykształcenie glottodydaktyczne. Immanentną część zawodu wraz z zapewnieniem indywidualnego doradztwa zawodowego przez specjalistów o najwyższych kwalifikacjach powinno stanowić doskonalenie i rozwój zawodowy. Bez zmian strukturalno-organizacyjnych, stworzenia odpowiednich warunków do realizacji (finansowych, organizacyjnych, kadrowych), bez zintegrowanego i na nowo przemyślanego kształcenia ogólnego i wyższego realizacja idei refleksji pozostanie jedynie działaniem pozornym.

Moje rozważania na temat refleksji w zawodzie nauczyciela chciałabym zakończyć myślą chińskiego filozofa „Niech Bóg da Wam pogodę ducha, byście akceptowali rzeczy, których nie możecie zmienić, odwagę byście zmieniali to, co możliwe i mądrość byście umieli dokonywać wyboru".

\section{BIBLIOGRAFIA}

Bauman, T. 2003. „Zagrożona tożsamość uniwersytetu” (w:) Uniwersytet - między tradycja a wyzwaniami współczesności (red. A. Ładyżyński i J. Raińczuk). Kraków: Impuls: 53-68.

Cylkowska-Nowak, M. 2013. „O nieszkodliwości wagarowania. Konsumpcyjne uwikłania ofiar i/lub sprawców pozoru w edukacji szkolnej" (w:) Sprawcy i/lub ofiary działań pozornych w edukacji szkolnej (red. M. Dudzikowa i K. Knasiecka-Falbierska). Kraków: Impuls: 300-322. 
Czerepaniak-Walczak, M. 1997. Aspekty i źródła profesjonalnej refleksji nauczyciela. Toruń: Edytor.

Czerepaniak-Walczak, M. 2011. „Studia III stopnia czy studia doktoranckie? O jednym z aspektów Procesu Bolońskiego" (w:) Jakość kształcenia akademickiego w świecie mobilności i ryzyka (red. H. Kwiatkowska i R. Stępień). Pułtusk: Wydawnictwo Akademii Humanistycznej: 25-38.

Denek, K. 2008. „Przewodnik po świecie wiedzy, wartości i życia” (w:) Kompetencje nauczyciela edukacji poczq̨tkowej (red. K. Żegnałek). Warszawa: Wydawnictwo WSP TWP: 43-56.

Dylak, S. 1996. „Kształcenie nauczycieli do refleksyjnej praktyki: zarys genezy, istoty i rozwoju koncepcji". Rocznik Pedagogiczny, 19: 35-60.

Elliott, J. 1991. Action Research for Educational Change. Buckingham: Open University Press.

Helsińska Fundacja Praw Człowieka. 2010. Prawo do edukacji dzieci o specjalnych potrzebach edukacyjnych. Raport z monitoringu (opr. J. Ciechanowski, B. Chmielewska, E. Czyż i Z. Kołodziej). Warszawa.

IBE. 2011. Raport o stanie edukacji 2010: Nauczyciele. www.ibe.edu.pl DW. 20.04.2013.

Klus-Stańska, D. 2008. „Dokąd zmierza polska szkoła? - pytania o ślepe uliczki, kierunki, konteksty" (w:) Dokq̨d zmierza polska szkoła (red. D. Klus-Stańska). Warszawa: ŻAK: 7-35.

Knasiecka-Falbierska, K. 2010. „Relacje nauczyciel-uczeń/uczniowie” (w:) Doświadczernia szkolne pierwszego rocznika reformy edukacji. Studium teoretycznoempiryczne, t.1. Kraków: Impuls: 174-199.

Kongres Obywatelski VI, 2011. www.kongresobywatelski.pl. opr. J. Ciechanowski, B. Chmielewska i in. DW 20.06.2013.

Kotusiewicz, A. 2008. „O niezbywalności autorefleksji w praktyce edukacyjnej nauczyciela akademickiego" (w:) Nauczyciel akademicki w refleksji nad własnq praktykq edukacyjnq (red. A. Kotusiewicz i G. Koć-Seniuch). Warszawa: ŻAK: 13-26.

Kwaśnica, R. 1994. Wprowadzenie do myślenia. O wspomaganiu nauczycieli $w$ rozwoju. Wrocław: Oficyna Nauczycielska WOM.

Kwaśnica, R. 2004. „Wprowadzenie do myślenia o nauczycielu” (w:) Pedagogika 2. Podręcznik akademicki (red. Z. Kwieciński i B. Śliwerski). Warszawa: PWN: 291-319.

Kwiatkowska, H. 1997. Edukacja nauczycieli. Konteksty-kategorie - praktyki. Warszawa: IBE. Kwiatkowska, H. 2008. Pedeutologia. Warszawa: Wydawnictwa Akademickie i Profesjonalne.

Kwiatkowska, H. 2011. „Jakość kształcenia - ale jaka?” (w:) Jakość kształcenia akademickiego w świecie mobilności i ryzyka (red. H. Kwiatkowska i R. Stępień). Pułtusk: Wydawnictwo Akademii Humanistycznej: 81-90.

Majewska, K. 2013 „Odświeżony nauczyciel”. Uniwersytet Warszawski. Pismo Uczelni 2(62).

Mizerek, H. 1999. Dyskursy współczesnej edukacji nauczycielskiej. Olsztyn: Wydawnictwo Uniwersytetu Warmińsko-Mazurskiego.

NIK: Jedna trzecia nauczycieli nie podnosi swoich kompetencji. 2012. PAP. http:// wiadomosci.onet.pl/kraj/nik-jedna-trzecia-nauczycieli-nie-podnosi-swoichkompetencji/qe0zt DW 30.10.2012. 
Potulicka, E. 2010a. „Pedagogiczne koszty reform skoncentrowanych na standardach i testowaniu" (w:) Neoliberalne uwikłania edukacji (red. E. Potulicka i J. Rutkowiak). Kraków: Impuls: 177-201.

Potulicka, E. 2010b „Wolny rynek edukacyjny a zagrożenia dla demokracji” (w:) Neoliberalne uwikłania edukacji (red. E. Potulicka i J. Rutkowiak). Kraków: Impuls: 99-112.

Potulicka, E. 2010c „Pytania o skutki neoliberalizmu. Aspekt jednostkowy” (w:) Neoliberalne uwikłania edukacji (red. E. Potulicka i J. Rutkowiak). Kraków: Impuls: 312-321.

Potulicka, E. 2011. „Studia pedagogiczne w neoliberalnym programie edukacji” (w:) Szkoła wyższa w toku zmian (red. J. Kostkiewicz, A. Domagała-Kręcioch i M. Szymański). Kraków: Impuls: 73-93.

Półturzycki, J. 2008. „Standardy kształcenia a kompetencje nauczycieli” (w:) Kompetencje nauczyciela edukacji poczq̨tkowej (red. K. Żegnałek). Warszawa: Wydawnictwo WSP TWP: 9-42.

Raszkowska, G. 2013. „Doktoranci bez doktoratu”. Rzeczpospolita (11.05.2013) http://www.rp.pl/artykul/1008159.html DW.11.05.2013.

Schön, D. 1983. The Reflective Practitioner. How Professionals Think in Action. London: Temple Smith.

Szempruch, J. 2000. Pedagogiczne kształcenie nauczycieli wobec reformy edukacji w Polsce. Rzeszów: Wydawnictwo Wyższej Szkoły Pedagogicznej.

Śliwerski, B. 2013. „Komitety naukowe PAN o edukacji” http://sliwerski-pedagog. blogspot.com DW 24.01.2013.

Thieme, J. 2009. Szkolnictwo wyższe. Wyzwania XXI w. Polska, Europa, USA. Warszawa: Difin. Wysocka, M. 1998. Samoocena nauczycieli języków obcych. Warszawa: Energeia.

Zawadzka, E. 2001. „Teoria a praktyka w kształceniu nauczycieli języków obcych”. Studia neofilologiczne WSP Częstochowa. (red. P. Płusa): 187-194. 